\begin{tabular}{|l|l|l|}
\hline Article Info & \multicolumn{1}{|c|}{ RESEARCH ARTICLE } & ARAŞTIRMA MAKALESI \\
\hline Title of Article & $\begin{array}{l}\text { An Evaluation on The Current Functions of } \\
\text { Madrasas in I stanbul Dating to 16th-18th Centuries } \\
\text { Regarding Their State of Conservation }\end{array}$ \\
\hline $\begin{array}{l}\text { Corresponding } \\
\text { Authors }\end{array}$ & $\begin{array}{l}\text { Engin ÖZTÜRK } \\
\text { Mimar, egnozturk@gmail.com }\end{array}$ \\
\hline $\begin{array}{l}\text { Submission Date } \\
\text { Admission Date }\end{array}$ & $\begin{array}{l}\text { 22/06/2019/25/08/2019 } \\
\text { ÖZTÜRK, E. ve ESMER, M. (2019). İstanbul'daki 16-18. Yüzyıllara Ait Medreselerin } \\
\text { Mevcut İşlevlerinin Koruma Amaçlı Değerlendirilmesi, Kent Akademisi, Volume 12, } \\
\text { Issue 3, Pages 561-574 }\end{array}$ & ORCID NO: \\
\hline How to Cite &
\end{tabular}

\title{
İstanbul’daki 16-18. Yüzyıllara Ait Medreselerin Mevcut İşlevlerinin Koruma Amaçlı Değerlendirilmesi
}

\section{ABSTRACT:}

The madrasas, which occupy an important place in the historical urban fabric of Istanbul, were established as institutions of higher and secondary education. In this paper, madrasas built between the $16^{\text {th }}-18^{\text {th }}$ centuries, starting with the Ottoman classical style and ending with the Ottoman baroque style until the beginning of the radical changes in the $19^{\text {th }}$ century, were handled. With the help of the archival documents and photographs, a comparison of the past and present states of preservation was accomplishable and in addition, the previous repairs of the structures were examined. Moreover, interviews which were conducted with the managers-in-charge helped to evaluate the approach of the current users towards the cultural heritage. In the study, the locations of madrasas, their plan types, known repairs, registration status and dates as cultural assets, relevant decrees of the board of conservation, known and current functions were identified. Considering that madrasas are also cultural assets, their users are expected to be aware of cultural heritage and its values. The needs and demands regarding a new function to a madrasa should be determined within the scope of the conservation projects by experts in terms of prioritizing the preservation of cultural heritage.

\section{KEYWORDS}

Istanbul, Madrasa, Educational Institutions, Re-Functioning, Preservation.

ÖZ:

Amaç: İstanbul'un Osmanlı Devleti’nin başkenti olarak bilim, eğitim ve kültür alanında önemli bir merkez olmasının doğal bir sonucu olarak başkentte pek çok eğitim yapısının inşa edilmiştir. İstanbul'un Osmanlı dönemi eğitim yapıları içinde medreseler önemli yer tutar. Bu araştırmada, başkent İstanbul'da Osmanlı klasik üslubunun yerleştiği 16. yy. ile köklü bir değişimin başladığı 18. yy sonuna kadar inşa edilen orta ve yüksek dereceli eğitim yapıları olan medreseler tespit edilerek, koruma sorunlarının belirlenmesine çalışılmıştır. Yöntem: Arşiv belgeleri ve eski fotoğraflar yardımı ile medreselerin geçmişteki ve günümüzdeki durumları karş̧laştırılarak, yapılan onarımlar irdelenmiştir. Bir alan çalışması ile tüm medreselerin mevcut durumları yerinde incelenmiştir. Ayrıca yönetici ve kullanıcılarla anket çalışması yapılarak kültürel mirasın ve kültürel değerlerin tanıtılması ve korunması konusundaki düşünceleri tespit edilmiştir. Bulgular: Çalışmada incelenen 61 medresenin 8 tanesinin 2017 yllında onarımda olduğu, 41 tanesinin vakıf/dernek, 12 tanesinin kamu hizmetinde (idari, iktisadi, sosyal ve bilimsel-teknik-kültürel hizmetlerde) kullanıldığı tespit edilmiştir. Ayrıca oldukça geç tescillendikleri belirlenmiştir. Sonuç: Medrese yapıları, aynı zamanda birer kültür varlığı oldukları için kullanıcılarından faaliyet gösterdikleri alan dışında, kültürel miras ve koruma konusunda bilinçlenmeleri ve kültürel değerleri korumaya yönelik çalışmalarda bulunmaları beklenmekte; medreselerin daha ziyade kamu yapısı olarak sosyal kamu hizmetleri ile bilimsel-teknik-kültürel kamu hizmetlerinde kullanılması tavsiye edilmektedir.

\footnotetext{
${ }^{1}$ Mimar, Restorasyon Uzmanı, egnozturk@gmail.com

${ }^{2}$ FSMVÜ, MTF, Mimarlık Bölümü, mesmer@fsm.edu.tr
} 


\section{ANAHTAR KELIMELER.}

İstanbul, Medrese, Eğitim Yapıları, Yeni İşlev Verme, Koruma /

\section{“İstanbul’daki 16-18. Yüzyıllara Ait Medreselerin Mevcut İşlevlerinin Koruma Amaçı Değerlendirilmesi”}

\section{GíRiș:}

İstanbul'un Osmanlı Devleti'nin başkenti olarak bilim, eğitim ve kültür alanında önemli bir merkez olması, bunun doğal bir sonucu olarak başkentte pek çok eğitim yapısının inşa edilmesini doğurmuştur. İstanbul'un Osmanlı dönemi eğitim yapıları içinde önemli bir yer tutan medreseler, İslam dünyasında Selçuklulardan itibaren devlet tarafindan desteklenmiş ve yönlendirilmiştir. Eğitim kurumları olarak medreseler, siyasi çekişmeler ve iktidar mücadelelerinde halkı etkileyen toplumsal meselelerin kamuoyu nezdinde ele alınıp, tartışılmasına ve değerlendirilmesine de katkıda bulunmuşlardır.

Fatih Sultan Mehmet'in (1451-1481) külliyesi içinde yaptırdığı Semaniye medreseleri sayesinde, İstanbul devlet merkezi olmakla kalmayıp ilim merkezi konumuna da ulaşmış; bu gelişim Mahmud Paşa, İbrahim Paşa, Davut Paşa gibi vezirler ve diğer önemli devlet adamlarıyla padişahlar tarafından I. Süleyman'ın hükümdarlığının (1520-1566) sonuna kadar devam etmiştir (Kütükoğlu, 2000: 4). Ancak, 16. yy.’da Sultan III. Murad devrinden (1574-1593) itibaren medreselerde bir bozulma başlamış; 18. yy.'da medreselerin giderek kötüleşen hali, ilerleyen Batı karşısında Osmanlı ilim ve fenninin çok geri kalması neticesini doğurmuştur (Kütükoğlu, 2000: 11). 18.yy.'1n sonundan itibaren medreselerdeki eğitim ile ilgili iyileştirme çabaları hız kazanmıştır. Batı ile arada açılan uçurumu telafi edebilmek için çağdaş yükseköğrenim kurumları olarak Mühendishane ve Tıbbiye mektepleri açılmıştır (Beydilli, 1995: 9). II. Mahmud devrinde (1808-1839) ise orta öğretim kurumları iyileştirilmeye çalışılıııs; sıbyan mekteplerinin üstünde eğitim vermek üzere rüşdiye ve idadiler açılmıştır (Kodaman, 1980: 19). İstanbul'dan başlamak üzere, ilk mekteplerin 1824 tarihli bir fermanla zorunlu hale getirilmesi, yine 19. yy.'daki köklü değişikliklerden biri olmuştur (Araz, 2013: 23). Çocukların eğitimi ve yetiştirilmesi Osmanlı Devleti'nde 19. yy.' dan evvel devletin ilgilendiği ve politika geliştirdiği bir mesele değildir (Araz, 2013: 100). 19. yüzyılda "Batılılaşma" dönemi olarak da adlandırılan modernleşme sürecinde, Osmanlı eğitim sisteminde gerçekleştirilen bu önemli değişikliklerle birlikte kaçınılmaz olarak eğitime yönelik mimarinin biçimlenişi de değişmiştir.

Bu araştırmada, başkent İstanbul'da Osmanlı klasik üslubunun yerleştiği 16. yy. ile köklü değişimin başlamasına kadarki süreçte, 18. yy sonuna kadar inşa edilen orta ve yüksek dereceli eğitim yapıları olan medreseler tespit edilerek, tarihsel ve mimari özellikleri açısından değerlendirilmiş ve halen mevcut olanlarının koruma sorunlarının belirlenmesine çalışılmıştır. Çalışmada medreselerin konumları, plan tipleri, bilinen onarımları, tescil durumları ve tarihleri, ilgili kurul kararları, bilinen ve güncel işlev ve koruma durumları incelenmiş; yapılarla ilgili sorunlar tespit edilerek, daha iyi korunmaları yönünde tavsiyeler işlevleri özelinde belirtilmiştir. 


\section{Medresenin Tanımı ve Mimari Özellikleri}

Medrese Arapçada "ders yapılan" ya da "ders çalışılan yer" anlamlarına gelmektedir (Kurşun, 2008: 36). "Çalışma yeri” anlamına gelen "me” öneki ile "öğrendi/sürekli okudu" anlamındaki "derese” fiilinden türetilmiş bir kelimedir. Tüm İslam devletlerinde olduğu gibi Osmanlı Devleti’nde de orta ve yüksek dereceli eğitim kurumları medreselerdir (Necipoğlu, 2008: 86). İslam dünyasında medreselerden önce, eğitim-öğretim faaliyetleri camilerde ve hocaların evlerinde verilmekteydi (Ahunbay, 1988: 240). Fakat nüfusun çoğalması ve diğer şehirlerden gelen öğrencilerin artması ile birlikte başka bir eğitim yapısına ihtiyaç duyularak medreseler kurulmuştur. Osmanlı medrese sistemi ilk devirde Anadolu Selçuklu ve Anadolu Beylikleri medrese sisteminin devamı olarak ortaya çıkmıştır. Yıldırım Bayezid (1389-1402) ve II. Murat (1421-1451) devirlerinde medreseler üzerinde bir derecelendirmeye ve düzenlemeye gidilmiştir (Kütükoğlu, 2000: 3). Medreseler eğitim verilen derslere göre farkl1lık göstermektedirler. Sibyan mekteplerindeki ilk eğitimden sonra gidilen genel medreselere türlerinin ilki denilebilir (Ahunbay, 1993: 321). $\mathrm{Bu}$ tür medreseler köylere kadar yayılmıştır. İkinci tür medreseler ise belli konularda ihtisaslaşmış olan medreselerdir (Ahunbay 1993: 321). Bunlar darülkurra, darülhadis, tıp medreseleridir. Darülkurralarda kıraat, mahreç eğitimi gibi eğitimler verilirken, darülhadislerde ise hadis eğitimi verilmektedir. (Ahunbay, 1993: 322). Padişah ve vezirlerce yaptırılan medreseler en üst sevide olanlardır. Her medreseyi tamamlayan öğrenci, orada bulunan müderristen icazetname alırdı (Kasmo, 2008:10). Bu icazetname ile bir sonraki eğitim basamağına geçilirdi. Müderrislerden İstanbul'da görevli olanlar buradan kadılığa, kazaskerliğe ve şeyhülislamlığa kadar yükselebilmektedirler (Ahunbay, 1993: 321).

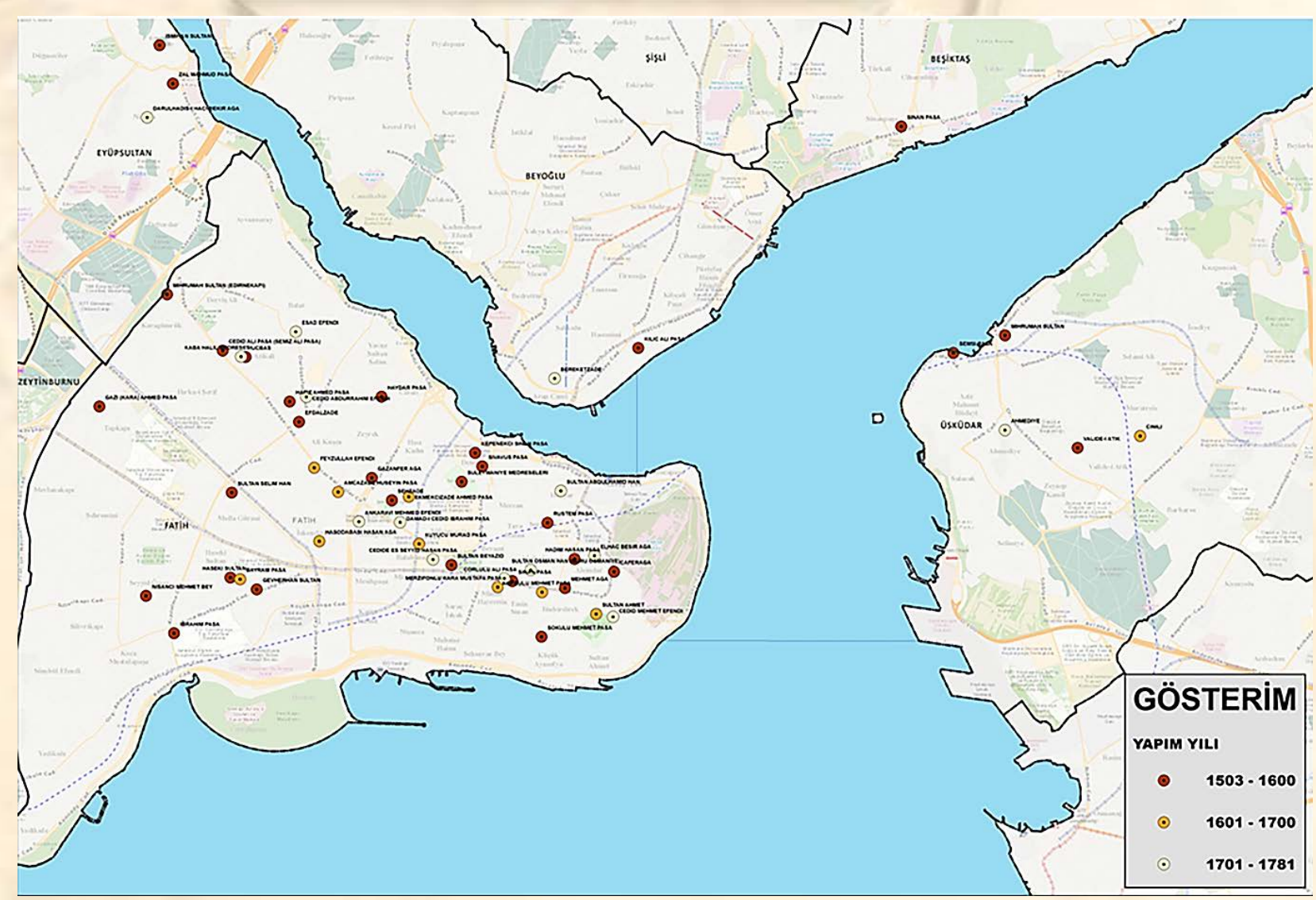

Şekil 1. İncelenen medreselerin konum ve yapım yıllarına göre dağılımları görülmektedir (Öztürk, 2018). 
Osmanlı döneminde etkinlik alanları genişleyen ve Tanzimat Dönemi’ne kadar sayıları artan medreseler için vakıflar kurulmuş, vakıflar mütevellileri tarafından idare edilmiştir. Medreselerin kontrolü ile sorumlu müderris ve mütevelli heyeti devlet tarafından atanmıştır. Vakıflar, bina yapmak, müderris ve talebelere maaş vermek, ihtiyaç içinde bulunanlara yardım etmek gibi görevler üstlenmişler ve öğrencilerin parasız eğitim almasına olanak sağlamışlardır (Kütükoğlu, 2000: 25). Öğrencilerin yiyecekleri aynı külliye programı içindeki imaretten sağlanmış ve bazı medreselerde öğrencilere günlük yevmiye de verilmiştir. Hatta Ramazan ayında çeşitli yerlere gönderilen öğrenciler, buralarda vaaz ettirilerek, namaz kıldırarak toplum önüne çıkarılmıştır (Kütükoğlu, 2000: 26). Böylece medreseler ile halk arasındaki iletişim kuvvetlendirilerek, insanların medrese kurumuna olan güvenleri arttırılmıştır. Ayrıca medreselerde düzenli olarak kayıt tutulmuştur (Kütükoğlu, 2000: 7). Vakıf olarak işletildikleri için odaların boş-dolu durumları, odada kaç kişinin kalacağı, evli olanların medresede kalmadıklarının kontrolü ${ }^{3}$, medresede ders veren müderrislerin görev süreleri gibi hususlar vakıf yönetimi tarafından takip edilmiştir (Kütükoğlu, 2000: 7).

İstanbul'da inşa edilmiş olan medreselerin Fatih İlçesi'nde yoğunlaştığı görülür (Şekil 1). Bu medreseler bir külliye veya manzumenin içinde veyahut da tek başlarına inşa edilmiştir (Kütükoğlu, 2000: 6). Günümüze ulaşan medreselerin kargir yapılar oldukları görülmektedir.
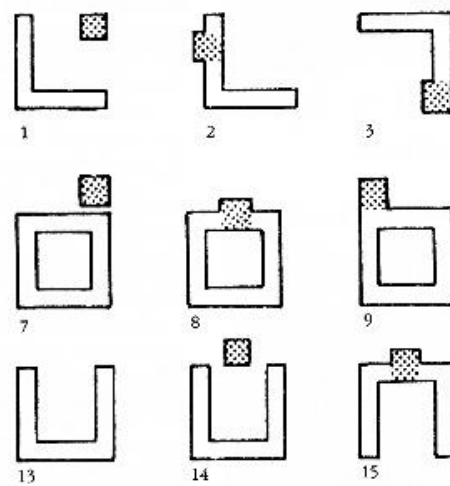
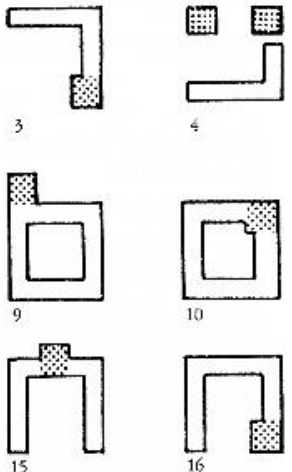
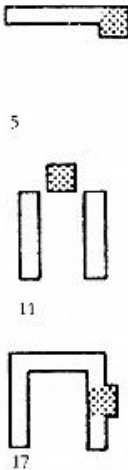

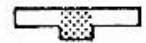

6
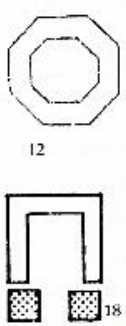

Şekil 2. Ahunbay’a göre hücrelerin dizilişleri ve dershane ile olan ilişkilerine bağlı olarak medrese plan düzenleri görülmektedir. 1-4 l-plan, 5-6 yanyana tek dizi, 7-10 dikdörtgen plan, 11 karşılıklı iki dizi, 12 sekizgen plan, 13-18 uplan (Ahunbay 1993: 325).

Medreseleri mimari özellikleri açısından değerlendiren ilk bilimsel çalışma Semavi Eyice’ye aittir (Eyice, 1979: 116118). 16-18. yy.’lar arası medreselerin incelendiği bu çalışmada Eyice, medreseleri bir külliye içinde yer almaları, bağımsız olarak yapılmış olmaları ve sultan medreseleri olarak üç başlıkta ele almıştır (Eyice, 1979: 116-118). Eyice’den sonra, Osmanlı eğitim yapıları üzerine Zeynep Ahunbay’ın yapmış olduğu kapsamlı çalışmada ise, medreselerin temel bileşeni olan dershanenin konumuna göre bir plan tipolojisi belirlenmiştir (Şekil 2). Bu tipolojiye göre medreseler altı ana başlıkta ele alınmıştır: 1. Yan yana tek dizi, 2. Karşılıklı iki dizi, 3. L-plan, 4. U-plan, 5. Dikdörtgen plan, 6. Sekizgen plandır (Ahunbay, 1993: 325). Sözkonusu altı farklı plan tipine örnek olarak: 1. Yanyana tek dizi için Süleymaniye Tıp Medresesi, 2. Karşılıklı iki dizi için Sokullu Mehmet Paşa Medresesi, 3. Lplan tipi için Köprülü Mehmet Paşa Medresesi, Merzifonlu Kara Mustafa Paşa Medresesi, 4. U-plan tipi için Sultan

${ }^{3}$ Osmanlı medreselerinde kalan talebeler, hücrelerinde kaldıkları sürece bekâr olmak durumundaydılar. 
Selim Medresesi, 5. dikdörtgen plan tipi için Kılıç Ali Paşa Medresesi ve 6. Sekizgen plan tipi için de Rüstem Paşa Medresesi verilebilir.

\begin{tabular}{|c|c|c|c|c|c|c|c|c|c|c|c|c|c|}
\hline & YAPMM YILI & MEDRESE isMi & $\begin{array}{l}\text { PLAN } \\
\text { TiPI }\end{array}$ & $\begin{array}{l}\text { TESCIL } \\
\text { TARIHÍ }\end{array}$ & GÖNCEL iŞLEV & $\begin{array}{l}\text { HARAP } \\
\text { HALDE }\end{array}$ & $\begin{array}{c}\text { RESTORASY } \\
\text { ONDA }\end{array}$ & $\begin{array}{l}\text { FiziKSEL } \\
\text { SOR. }\end{array}$ & $\begin{array}{l}\text { ISŞLEVSEL } \\
\text { SOR. }\end{array}$ & $\begin{array}{l}\text { RESTORAS } \\
\text { YON SOR. }\end{array}$ & $\begin{array}{l}\text { MLALZEME } \\
\text { SOR. }\end{array}$ & $\begin{array}{l}\text { STRÖKTŨ } \\
\text { REL SOR. }\end{array}$ & $\begin{array}{l}\text { GENEL } \\
\text { DE,GERLENDIRME }\end{array}$ \\
\hline 1 & 1503 & EFDALZADE MEDRESESt & U-plan & 17.07.1987 & Dernek & & & $\mathbf{x}$ & $\mathbf{x}$ & $\mathbf{x}$ & $\mathbf{x}$ & $\mathbf{x}$ & KÖTÖ \\
\hline 2 & 1506 & SULTAN BEYAZID MEDRESEST & U-plan & 16.09 .1987 & Kätîlphane & & $\mathrm{x}$ & & & & & & RESTORASYON \\
\hline 3 & 1533 & ŌÇBAȘ MEDRESESI & U-plan & 16.09 .1987 & Dernek & & $\mathbf{x}$ & & & & & & RESTORASYON \\
\hline 4 & 1541 & TERCOMAN YUNUS MEDRESEST & & 16.09 .1987 & Mâftallak-kurs & & & & & & & & $\mathrm{frI}$ \\
\hline 5 & 1539 & HASEKI SULTAN MEDRESESI & U-plan & 16.12 .1992 & Diyanet-eğtitim $\mathrm{m}$. & & & & $\mathbf{x}$ & & & & tyt \\
\hline 6 & 1547 & ȘEHZADE MEDRESESI & U-plan & 9.08 .1977 & Vakif & & & & & & & & \\
\hline 7 & 1545 & KEPENEKCุI SINAN PASA MEDRESESI & L-plan & 9.04.1977 & Harap durumda & $\mathbf{x}$ & & & & & & & RESTORASYON \\
\hline 8 & 1548 & MIHRTMAH SULTAN (ÚSKÖDAR) MEDRESESI & U-plan & 14.04.1973 & Tip merkeri & & & $\mathrm{x}$ & $\mathrm{x}$ & & & & trt \\
\hline 9 & 1549 & SULTAN SELIM MEDRESESI & U-plan & 24.06 .1992 & Klinik & & & $\mathbf{x}$ & $\mathbf{x}$ & $\mathbf{x}$ & $\mathbf{x}$ & & KŌTƠ \\
\hline 10 & 1550 & ROSTEM PASSA MEDRESESI & 8-pen $p$. & 24.06 .1962 & Demek & & & & & $\mathbf{x}$ & $\mathbf{x}$ & & fYI \\
\hline 11 & 1556 & HAYDAR PASSA MEDRESESI & U-plan & 2.07 .1987 & Mescid & $\mathbf{x}$ & & & & & & & RESTORASYON \\
\hline 12 & 1556 & SiNAN PAȘA MEDRESESI (BEȘiKTAȘ) & U-plan & 13.01 .2004 & Mutflatuk-kurs & & & & & & $\mathbf{x}$ & & tyt \\
\hline 13 & 1558 & SOLEYMANTYE KOLLIYESI EVVEL MEDRESE & kare & 9.04 .1977 & Kattuphane & & & & & & & & trt \\
\hline 14 & 1558 & SOOLEYMANIYE KÖLLIYESI SANI MEDRESE & kare & $9,04.1977$ & Kätíphane & & & & & & & & fYi \\
\hline 15 & 1558 & SOLLYYMANTYE KOLLUYESI SALIS MEDRESE & kare & 9.04 .1977 & Oniversite & & & & & & & & tyi \\
\hline 16 & 1558 & SOLEYMANIYE KOLLLYESI RABI MEDRESE & kare & 9.04 .1977 & TUBA & & & & & & & & tYT \\
\hline 17 & 1558 & SÓLEYMANTYE KÓLLIYESI TIP MEDRESESI & tek dizi & 9.04 .1977 & Kitap onanm mer. & & & & & & & & tri \\
\hline 18 & 1558 & SÜLEYMANTYE KÖLLYYESI DARÖLKURRA & & 9.04 .1977 & ișlevsiz & & & & & & & & trt \\
\hline 19 & 1558 & SÖLEYMANTYE KÖLLIYESI DARÓLHADIS & L-plan & 9.04 .1977 & Oniversite & & & & & & & & tyt \\
\hline 20 & 1558 & SOLLEYMANYYE KOULLYYSI MOLLAZTMLAR MEDRESESI & & 9.04 .1977 & Oniversite & & & $\mathbf{x}$ & & & $\mathbf{x}$ & & fyl \\
\hline 21 & 1560 & CAFERAŌAMEDRESESİ & U.plan & 12.06.1976 & Vakafticaret & & & $\mathbf{x}$ & $\mathbf{x}$ & $\mathbf{x}$ & $\mathbf{x}$ & & KÖTŨ \\
\hline 22 & 1560 & ESEKAPI (ISAKAP) MEDRESESt & & 16.12.1992 & Yesilay merkezi & & & $\mathbf{x}$ & & & & & tYI \\
\hline 23 & 1565 & GAZI (KARA) AHMED PAȘA MEDRESESI & U-plan & 24.06 .1992 & Ögrenci yurdu & & & & & & & & tYI \\
\hline 24 & 1568 & CEDID ALL PAȘA (SEMIZ ALI PAȘA) MEDRESESI & U-plan & 14.03.1981 & Vakif & & & $\mathrm{x}$ & $\mathbf{x}$ & & $\mathbf{x}$ & $\mathbf{x}$ & KÖTU் \\
\hline 25 & 1568 & HASEKI OEVHER SULTAN MEDRESESt & U.plan & 16.12 .1992 & Dernek & & $\mathbf{x}$ & & & & & & RESTORASYON \\
\hline 26 & 1569 & MIHRIMAH SULTAN (EDIRNEKAPI) MEDRESESI & U-plan & 24.06 .1992 & Demek & & & $\mathbf{x}$ & & & & & IYI \\
\hline 27 & 1569 & ISMIHAN SULTAN MEDRESESI & $\begin{array}{c}\text { dikdōontg } \\
\text { en }\end{array}$ & 15.01 .1977 & 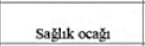 & & $\mathrm{x}$ & & & & & & RESTORASYON \\
\hline 28 & 1571 & SOKULLU MEHMET PAȘA MEDRESESI & iki dizi & 10.09 .1982 & Múftulatuk-kurs & & & $\mathrm{x}$ & & & $\mathrm{x}$ & $\mathbf{x}$ & ORTA \\
\hline 29 & 1580 & MEHMET AĜA MEDRESESI & U-plan & 14.07 .1978 & Yazarlar Birligi Mer. & & & $\mathrm{x}$ & $\mathbf{x}$ & $\mathbf{x}$ & $\mathrm{x}$ & $\mathrm{x}$ & KÖTÔ \\
\hline 30 & 1580 & KIICC ALI PAŞA MEDRESEST & kare & 15.10 .2003 & Vakuf & & & & $\mathbf{x}$ & & & & fYt \\
\hline 31 & 1580 & ȘEMSI PASA MEDRESESI & L-plan & 14.04 .1973 & Kütüphane & & & & & & & & fyl \\
\hline 32 & 1582 & ZAL MAHMUD PASSA MEDRESESI & U-plan & 15.01.1977 & Sahaflar çarşısı & & & $\mathbf{x}$ & & $\mathbf{x}$ & $\mathbf{x}$ & & ORTA \\
\hline 33 & 1583 & VALIDE-I ATtK MEDRESEST & U-plan & 14.04 .1973 & Dernek & & & $\mathrm{x}$ & $\mathbf{x}$ & & & & ORTA \\
\hline 34 & 1590 & GAZANFER AO̊A MEDRESESt & U-plan & $16,09,1987$ & Vakif & & & & $\mathrm{x}$ & & & & tYI \\
\hline 35 & 1593 & SLNAN PASSA MEDRESESI (BEYAZTI) & U-plan & 26.01 .2005 & Vakaf & & & $\mathrm{x}$ & & $\mathrm{x}$ & $\mathrm{x}$ & & KöTÔ \\
\hline 36 & 1596 & HAFZZ AHMED PASSA MEDRESESI & U-plan & 4.08 .1963 & Demek & & & $\mathbf{x}$ & & $\mathbf{x}$ & $\mathbf{x}$ & & KöTƠ \\
\hline 37 & 1597 & HADIM HASAN PASSA MEDRESESt & & 19.01 .1980 & Vakif & & & $\mathrm{x}$ & $\mathbf{x}$ & $\mathbf{x}$ & $\mathbf{x}$ & & KÖTƯ \\
\hline 38 & 1610 & KUYUCU MURAD PAȘA MEDRESESI & L-plan & 14.03 .1990 & Oniversite & & $\mathrm{x}$ & & & & & & RESTORASYON \\
\hline 39 & 1619 & SULTANAHMET MEDRESESI & $\begin{array}{c}\text { dikdốrtg } \\
\text { en }\end{array}$ & 26.01 .2005 & Vakif & & & & $\mathbf{x}$ & & & & ORTA \\
\hline 40 & 1635 & BAYRAMPASSA MEDRESESt & U-plan & 16.12 .1992 & Dennek & & $\mathbf{x}$ & & & & & & RESTORASYON \\
\hline 41 & 1640 & ÇNLII MEDRESE & L-plan & 14.04 .1973 & Demek & & $\mathbf{x}$ & & & & & & RESTORASYON \\
\hline 42 & 1659 & HASODABASSI HASAN AOCA MEDRESESt & U-plan & Tescilsiz & Demek & & & & $\mathbf{x}$ & $\mathbf{x}$ & & & ORTA \\
\hline 43 & 1661 & KÖPROLLO MEHMET PAŞA MEDRESESt & L-plan & 18.10.1989 & Vakif-Kubbealt & & & $\mathrm{x}$ & & & $\mathrm{x}$ & & ORTA \\
\hline 44 & 1664 & NIȘANCI MEHMED PASSA MEDRESESt & L-plan & 16.12.1992 & Vakif & & & & $\mathrm{x}$ & & & & trt \\
\hline 45 & 1691 & MERZIFONLU KARA MUSTAFA PAŞA MEDRESESI & L-plan & 18.10.1989 & Vakif-Kubbealt & & & $\mathbf{x}$ & & & $\mathrm{x}$ & & ORTA \\
\hline 46 & 1700 & AMCAZADE HÖSEYIN PAȘA MEDRESESt & U-plan & $24,06.1992$ & Müze-kapalı & & & $\mathbf{x}$ & $\mathbf{x}$ & $\mathbf{x}$ & $\mathbf{x}$ & $\mathbf{x}$ & KÖTÛ \\
\hline 47 & 1700 & FEYZULLAH EFENDI MEDRESESI & L-plan & 24.06 .1992 & Millet Kuttaphanesi & & & $\mathbf{x}$ & & & & & tyi \\
\hline 48 & 1705 & CEDID MEHMET EFENDI MEDRESESI & U-plan & 10.09 .1988 & Sanatkarlar Çarşısı & & & & $\mathrm{x}$ & & $\mathrm{x}$ & & tyt \\
\hline 49 & 1705 & BEREKETZADE MEDRESES! & L-plan & 12.03 .1983 & Cami & & & $\mathbf{x}$ & $\mathbf{x}$ & $\mathbf{x}$ & $\mathbf{x}$ & $\mathrm{x}$ & KÖTƯ \\
\hline 50 & 1707 & ANKARAVI MEHMED EFENDI MEDRESESI & U.plan & 7.05 .1953 & Vakif & & & $\mathbf{x}$ & $\mathbf{x}$ & & $\mathbf{x}$ & $\mathbf{x}$ & KÖTŨ \\
\hline 51 & 1716 & ÇORLULU ALL PAŞA MEDRESESI & Lplan & 26.01 .2005 & Kafe-ticaret & & & $\mathrm{x}$ & $\mathbf{x}$ & $\mathrm{x}$ & $\mathrm{x}$ & $\mathbf{x}$ & KÖTÖ \\
\hline 52 & 1717 & DAMAD IBRAHIM PASSA MEDRESESI & U-plan & 9.04 .1977 & Vakif & & $\mathbf{x}$ & & & & & & RESTORASYON \\
\hline 53 & 1722 & AHMEDIYE MEDRESESI & L-plan & 14.04.1973 & Muttaltuk-kurs & & & $\mathbf{x}$ & & $\mathbf{x}$ & & & ORTA \\
\hline 54 & 1724 & ESAD EFENDI MEDRESESt & U.plan & $16,08.1987$ & Kötüphane & & & & & & $\mathrm{x}$ & & tYI \\
\hline 55 & 1735 & DAROLHADIS-I HACI BEȘIR AĞA & L-plan & 2.02 .2000 & Vakif & & $\mathrm{x}$ & & & & & & RESTORASYON \\
\hline 56 & 1745 & ELHAC BEȘIRAŎA MEDRESESI & U-plan & 12.11 .2003 & Demek & & $\mathbf{x}$ & & & & & & RESTORASYON \\
\hline 57 & 1746 & SEYYID HASAN PAŞA MEDRESESI & U.plan & 9.05 .1970 & Oniversite & & & $\mathbf{x}$ & & $\mathbf{x}$ & $\mathbf{x}$ & & ORTA \\
\hline 58 & 1754 & KABA HALIL MEDRESESI & U-plan & 14.03 .1981 & Vakıf & & $\mathbf{x}$ & & & & & & RESTORASYON \\
\hline 59 & 1747 & CEDID ABDORRAHIM EFENDI MEDRESESI & U.plan & 16.09 .1987 & Mutftulak-kurs & & & $\mathrm{x}$ & & $\mathbf{x}$ & $\mathrm{x}$ & $\mathrm{x}$ & KÖTƠ \\
\hline 60 & 1756 & NURUOSMANIYE MEDRESESI & U-plan & 26.01 .2005 & Mutftulak-kurs & & & & & $\mathbf{x}$ & & & tYI \\
\hline 61 & 1781 & HAMIDIYE MEDRESESI & $\begin{array}{c}\text { dikdóntg } \\
\text { en }\end{array}$ & 22.11 .2000 & $\begin{array}{l}\text { Istanbul Ticaret } \\
\text { Borsast }\end{array}$ & & & $\mathrm{x}$ & $\mathrm{x}$ & $\mathbf{x}$ & $\mathrm{x}$ & $\mathbf{x}$ & KÖтUิ \\
\hline
\end{tabular}

Şekil 3. İncelenen medreselerin isimleri, plan tipleri, tescil tarihleri, güncel işlevleri ile korunma durumlarını gösterir tablo (Öztürk, 2018).

\section{Medreselerin İşlevlerine Yönelik Tespit ve Sorunlar}

Osmanlı eğitim yapılarına ait birçok araştırma, yayın vb. çalışmalar bulunmasına karşın, medreselerin kapatıldığ $1^{4}$ yıl olan 1924 yılından sonra farklı işlevlerle kullanılan bu yapıların işlev-kaynaklı koruma sorunları mimari bir bütünlük içinde ele alınmamıştır. Bu konudaki tek istisna, Zeynep Ahunbay' ın "İstanbul Medreseleri, Koruma ve Yeniden Kullanım Açısından Bir Değerlendirme" başlıklı doçentlik tezidir ${ }^{5}$. İstanbul'daki medreselerin çok kapsamlı biçimde ele alınarak değerlendirildiği bu çalışmanın 1980'de tamamlanmasının ardından geçen 39 yıl içinde yapılarda ve işlevlerinde çeşitli değişimler olmuştur. Bu makalenin hazırlık aşamasında İstanbul medreseleri 16.-18. yy’ lar ile

${ }^{4}$ Türkiye Büyük Millet Meclisi’nde 3 Mart 1924’te Tevhid-i Tedrisat (Öğretim Birliği) Kanunu kabul edildi. Bu kanunla, medreseler kaldırıldı ve Türkiye Cumhuriyeti sınırları içindeki bütün okullar, Milli Eğitim Bakanlığı’na bağlandı.

${ }^{5}$ Basılı olmadığı için kaynakçada bu çalışma yer almamaktadır. 
sınırlandırılmıştır. Osmanlı Klasik üslubunun yerleştiği 16. yüzyıl ile eğitim yapılarının hem mimari hem de eğitim biçimleri açısından radikal biçimde değişmeye başladığı 18. yüzyıl sonuna kadarki süreç ele alınmıştır.

Çalışmada işlev değişikliklerinin yanı sıra yapılan müdahaleler ile deprem vb. doğal afetler nedeniyle özgün planları, cephe düzenleri ve malzemeleri değiştirilen bu kültür varlıklarının günümüzde sahip olduğu koruma sorunları tespit edilerek; bunların giderilmesi yönünde yaklaşımlar belirlenmeye çalışılmıştır. Bu amaca yönelik olarak, İstanbul'daki 16-18. yüzyıllara ait medreselerden günümüze ulaşan 61 tanesi arşiv belgelerinin incelenmesi, literatür taraması ve saha çalışmalarında gerçekleştirilen yerinde tespitler ile ele alınmış; aynı döneme ait olduğu bilinen fakat günümüze ulaşamamış 33 medrese güncel işlevleri kapsamında değerlendirilemeyecekleri için kapsam dışında bırakılmıştır. Çalışma kapsamındaki medreselerin plan tipleri Ahunbay’ın tipolojik çalışmasına göre değerlendirilmiştir. Çalışmada incelenen 61 medresenin 8 tanesinin 2017 yılında onarımda olduğu, 41 tanesinin vakıf/dernek, 12 tanesinin kamu hizmetinde (idari, iktisadi, sosyal ve bilimsel-teknik-kültürel hizmetlerde) kullanıldığı tespit edilmiştir (Şekil 3).

Geçmişe ait bu eğitim yapıları, günümüzde bulundukları konum ve kadastral durumları ile tanımlandıktan sonra tarihçe, mimari özellikler ve koruma sorunları başlıkları altında ayrıntılı olarak irdelenmiştir. Bu irdelemeler sonucunda ortaya çıkan koruma sorunlarını aşağıdaki başlıklar altında toplamak mümkündür.

\subsection{Yapıların tahsis edildikleri kullanıcıların nitelikleri, verilen işlevlerin yapıların tarihi kimliği ve} değeri ile bağdaşmaması ve eğitim yapıları olarak özgün vakfedilme amacının dıșına çıkılması

İncelenen yapıların kadastral durumları hakkındaki bilgiler, ilgili koruma kurullarının arşivlerinden, ulaşılabilen tapu kayıtlarından ya da İBB Kültürel Miras Koruma Müdürlüğü arşivinden temin edilmiştir. Medreselerin kullanımlarının kamu ve vakıflar tarafından olmak üzere iki ana kategoriye ayrıldığı söylenebilir. Medreselerin kamu ve vakıf idaresi olmak üzere devlet kuruluşlarınca kullanılıyor olmaları korunmaları yönünde bir güvence gibi görünse de; vakıf veya dernek olarak kullanılan bazı yapıların işlev değiştirirken özgün niteliklerini kaybettikleri gözlemlenmiştir. Bunu örnekle açıklamak gerekirse; bir vakfın genel merkezi olarak kullanılan bazı medreseler, vakıf yönetimindeki üst düzey kişilerin özel kullanımına tahsis edilmekte ve kamusal fayda sağlama ile eğitim odaklı olan vakfedilme amaçlarından çok uzaklaşmaktadırlar. Yeni bir yapıya da kolayca verilebilecek böyle bir işlev asıl işlevi eğitim olan medreseler için uygun değildir. Genel olarak tüm medreseler kamu yararı gözetilerek halka açık olmalı ve buralarda eğitim işlevinin sürdürülmesine olanak tanınmalıdır. Örneğin bu yapılarda İSMEK gibi kurumların halk sanatları, el işleri, Osmanlıca, ebru vb. eğitimleri verilebilir. Bunun dışında bazı medreseler ise kullanılıyor gibi görünmekle birlikte aslında çoğu birimleri boş ve harap durumdadır. Buna örnek olarak Fatih’te bulunan Efdalzade Medresesi gösterilebilir (Şekil 4). Günümüzde mescit ve eğitim merkezi işlevleriyle kullanılan medrese ivedilikle bilimsel bir onarıma ihtiyaç duymaktadır.

Medreselerin tahsis edildikleri kullanıcıların kültürel mirası koruma bilincine sahip olmamaları da sorunlara neden olan başka bir husustur. Bu durum, yapının özgün kimliğiyle bağdaşmayan uygulamaların önünü açmaktadır. Ayrıca yapılan müdahalelerde günümüz konfor koşullarını karşılamak üzere yapılara aşırı bir tesisat yükü gelmektedir. Modern yaşamın getirdiği teknolojik olanaklardan yararlanma isteği de bir sorun oluşturmaktadır. 


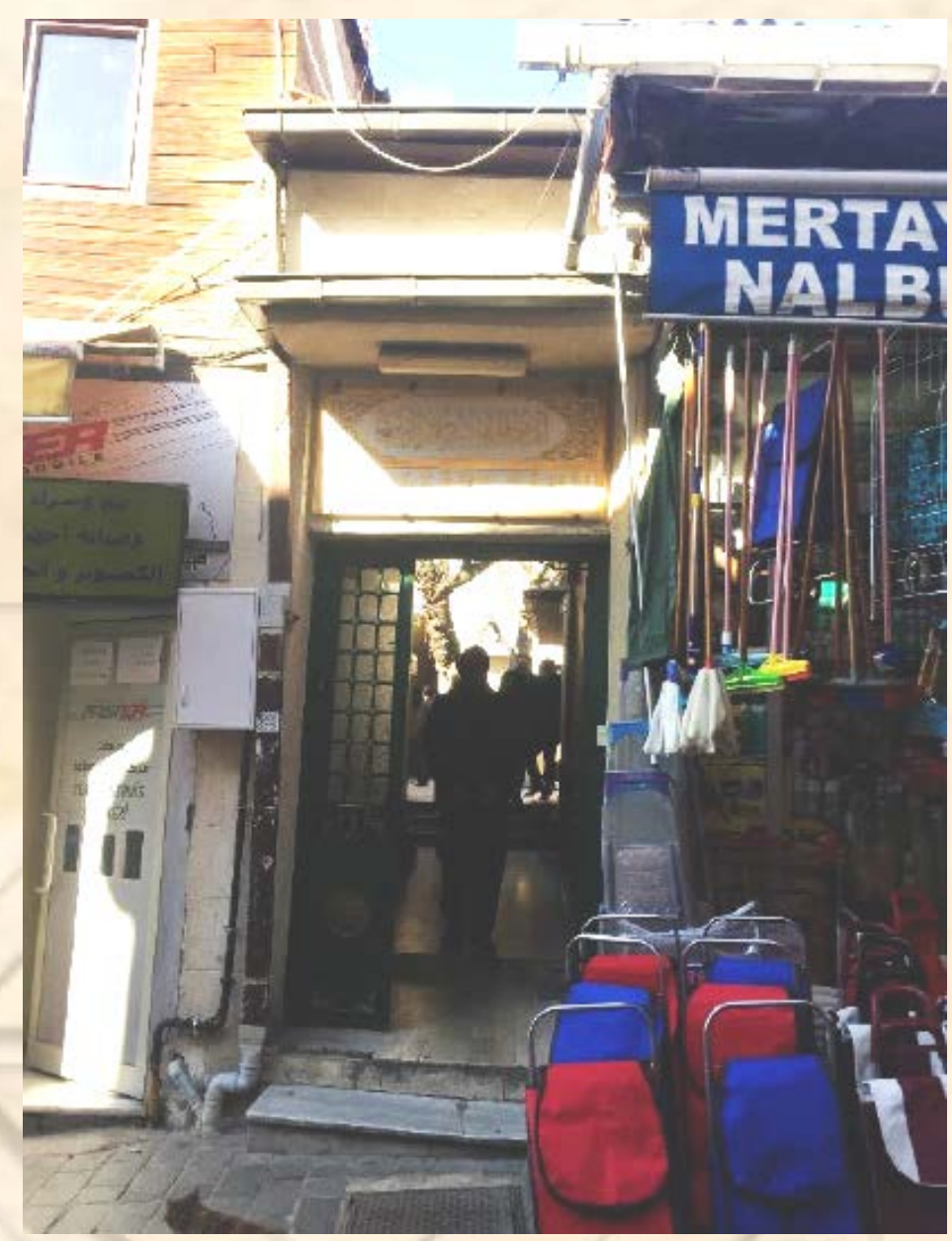

Şekil 4. Efdalzade medresesi girişi (Öztürk, 2017)

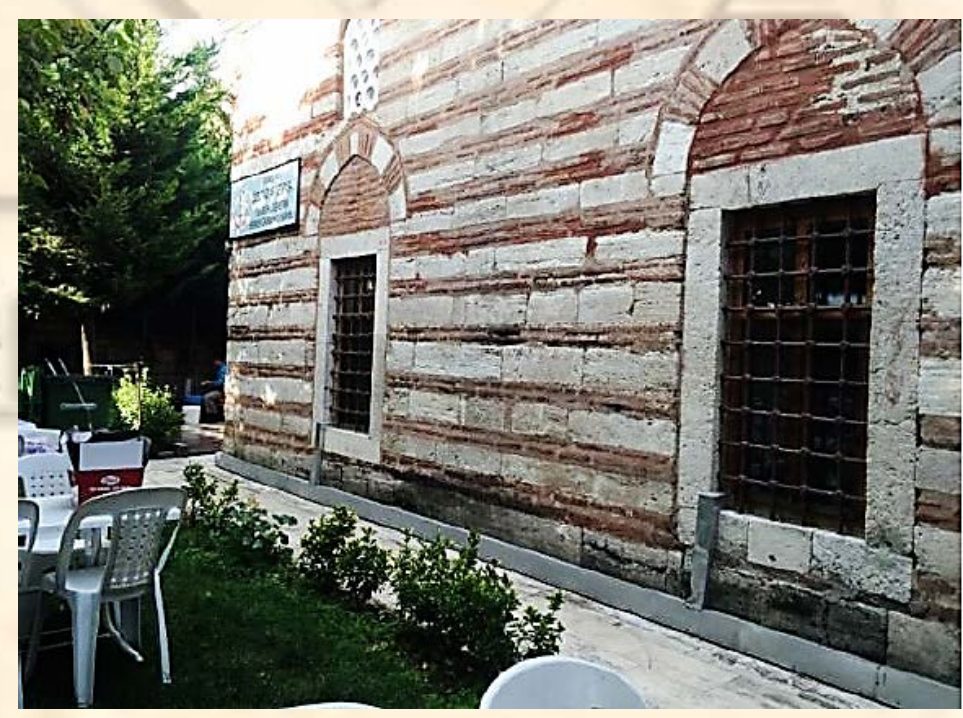

Şekil 5. Gazi Kara Ahmet Paşa medresesinin yurt olarak kullanımından dolayı cephede tesisat kanalı görülmektedir (Öztürk, 2017).

Yeniden kullanım sürecinde yapılar kabul edilebilir bir yaşam standardına yükseltilirken, özgünlüğü, bütünlüğü ve anlamı saygı görmelidir. Özellikle koruma bilincinden yoksun olunması, ekonomik boyutun çok fazla ön plana 
çıkarılmasına neden olmaktadır. Örnek vermek gerekirse, klima sistemlerinde VRF sistem olarak tek bir üniteye bağlı bir sistem kurulabilecekken, maliyetten kaçınarak split klima sistemleri ile hem medreselerin cepheleri bozulmakta, hem de birbirinden bağımsız bir çok tesisat elemanı (kablo,boru vb.) özgün doku tahrip edilerek duvarlardan geçmektedir.

Bu duruma Üsküdar Mihrimah Sultan Medresesi örnek olarak gösterilebilir. Bir sağlık merkezi olarak kullanılan medreseye gerek dershanesinin röntgen odası olarak tamamen içe dönük bir işlevle kullanılması, gerekse avlusunun uygun olmayan bir işlevle kapatılması gibi uygun olmayan ekler dışında, çok da ağır bir tesisat yükü getirilmiştir. Keza yurt olarak kullanılan Gazi Kara Ahmet Paşa medresesi için de benzer durum söz konusudur. Yurt kullanımının getirdiği ağır tesisat yükü yapının özgünlüğüne, mimari bütünlüğüne zarar vermektedir (Şekil 5).

\subsection{Yapıların Birer Külttür Varlığı Olarak Geç Tescil Edilmeleri}

Tarihi bir çevrede yapılacak kentsel planlama çalışmalarında gerekli pek çok ve hatta kimi zaman oldukça karmaşık nitelikte zorunlu unsur bulunsa da, en temel aşamalarından biri, mevcut tarihi alana dair kapsamlı ve multidisipliner bir araştırmanın gerçekleştirilmesi, araştırmalardan elde edilen bilgi birikimin derlenmesi ve bir envanter oluşturulmasıdır (Benli ve Özer, 2018:96). Kültür varlıklarının yasalar ile koruma altına alınabilmeleri için eserler ile ilgili envanter çalışmalarının tamamlanarak, anıt fişlerinin doldurulması ve tescil edilmeleri gerekmektedir. Çalışmada incelenen medreselerin tescil tarihlerinin oldukça geç olduğu tespit edilmiştir. İncelenmiş olan 61 medresenin 60'1 tescillidir. 1950-1960 arası 1 medrese,1960-1970 arası 2 medrese,1970-1980 20 arası medrese, 1980-2000 aras1 27 medrese, 2000 ve sonrasında ise 10 medrese tescil edilmiştir (Şekil 3).
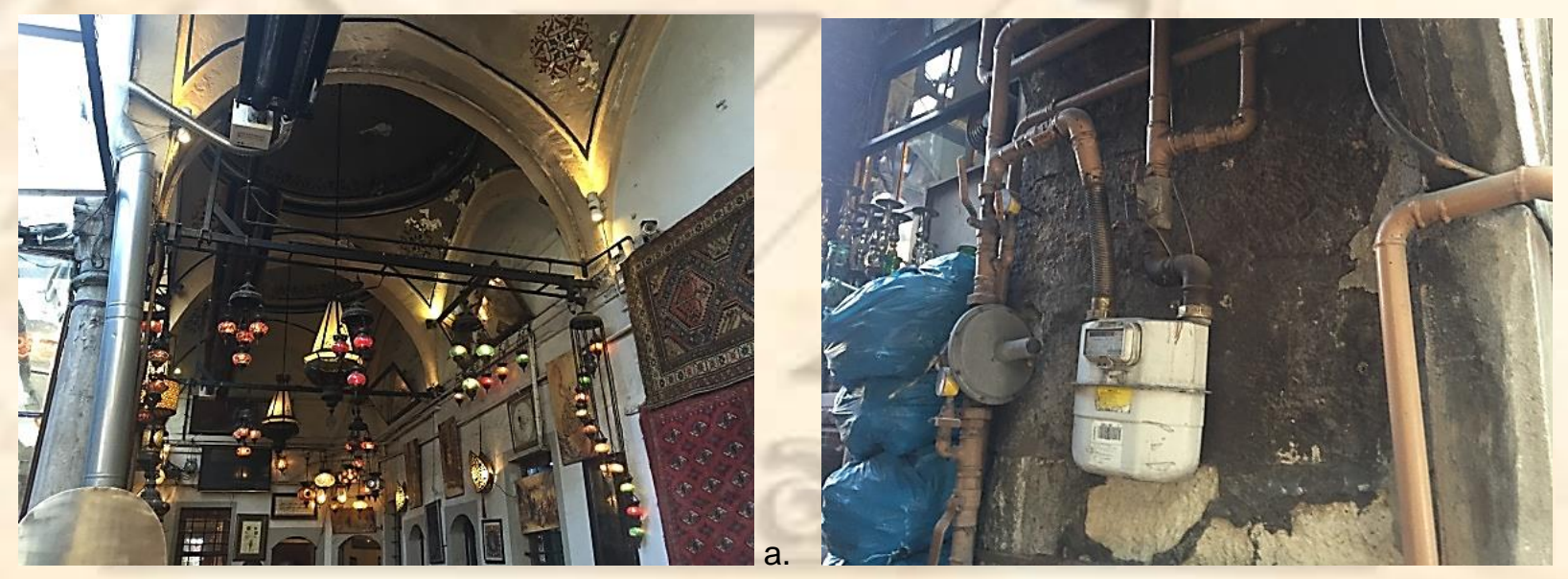

b.

Şekil 6. Çorlulu Ali Paşa Medresesi’nin güncel işlevinden kaynaklanan yapının iç mekanında aşırı tesisat yükü ve ticari eşyalarla kültürel miras algısının yok edilmesi (Öztürk, 2017).

Tescil işleminin geç yapılması medreselerin herhangi bir kontrol mekanizması olmaksızın tüm müdahale ve değişikliklere açık bulunmasına yol açmıştır. Medreseler geçirdikleri onarım ve müdahaleler öncesindeki halleri ile ayrıntılı olarak belgelenmemiş; bunun yanı sıra koruma gruplarının belirlenerek yapılabilecek müdahalelere sınır getirilmesi de 2000 yılından sonra gerçekleşmiştir. En geç tescil edilen medreselere örnek olarak 2005 yılında tescilleri gerçekleşen Çorlulu Ali Paşa ve Sultanahmet Medreseleri verilebilir. Bu gecikme yapıların korunması konusunda bir zafiyet yaratmıştır (Şekil 6). 


\subsection{Proje, İhale veRestorasyon Sürecinde Yașanan Aksaklık ve Sorunlar}

Restorasyonun proje, ihale ve uygulama aşamalarında pek çok sorun ile karşılaşılmaktadır. Bunlar restorasyon öncesi yetersiz hazırlanan projelerden, ihale sürecinden, eski eser restorasyonunda kullanılan malzemelerin niteliği ve temininden, restorasyon uygulamalarında çalışan kalifiye eleman eksikliğinden, verilen yeni işlevin uyumsuzluğundan kaynaklanan sorunlar olmak üzere kısaca özetlenebilir.

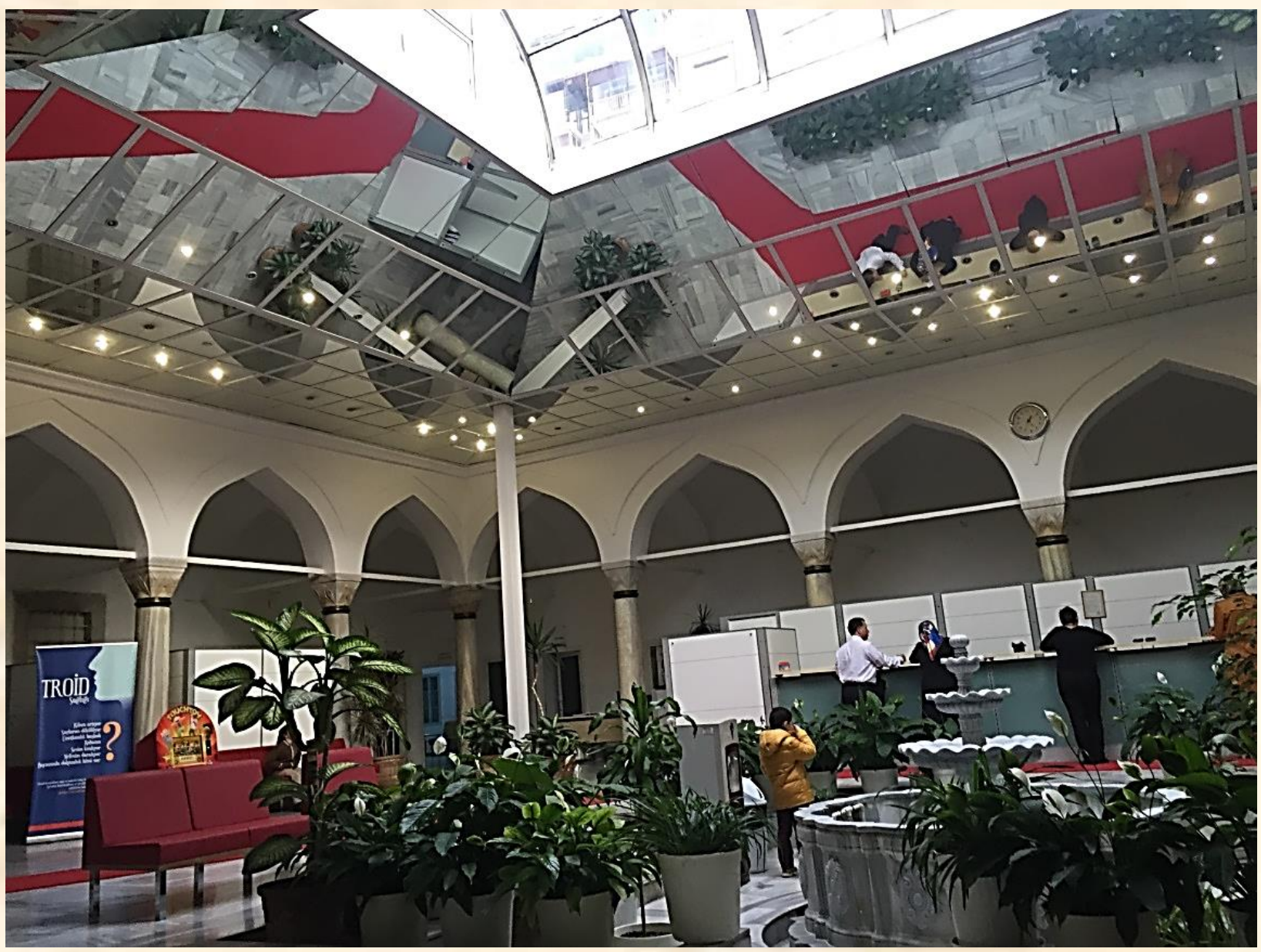

Şekil 7. Sağlık merkezi olarak kullanılan Üsküdar Mihrimah Sultan Medresesi’nde kapatılmış olan iç avlu (Esmer, 2018).

Yapılan incelemeler sonucu, herhangi bir medrese için bir onarım yapılması gündeme geldiği zaman, ihale ve projelendirme sürecinin çok uzun sürdüğü ve bu süreçte yapıdaki hasarların arttığı tespit edilmiştir. Örneğin külliye yapılarının farklı kuruluşlarca kullanılması nedeniyle bir külliyeye bağlı medreselerde ortak bir yönetim anlayışı ve bütçe dengelemesi yapılamadığından bütünü kapsayan bakım ve onarım çalışmaları aksamaktadır (Ekimci ve Ahunbay, 2016: 8). Projelerin resmi kurumlarca onaylanmasının ardından, uygulama ihalesine çıkılması ve onarımın başlaması da 5-6 yıl gibi bir süreyi bulabilmektedir. Bu süre çeşitli medreselerin kurul kayıtlarındaki proje onay tarihleri ile onarımlarının yapıldığı tarihlerde, projelerde yapılan revizyonlar ve/veya tashihlerin yine kurul dosyasındaki karar tarihleri karşılaştırılarak ortaya çıkarılmıştır. Bu durumda medrese için hazırlanan müdahale paftaları da geçen zaman zarfında güncelliğini yitirebilmektedir. Buna örnek olarak Kepenekçi Sinan Paşa Medresesi 
verilebilir. Günümüzde onarılmayı bekleyen medresenin proje çalışması 2000'lerin başında hazırlanmaya başlamış, 2008 'de ilgili bölge kurulu tarafından onaylanmış ${ }^{6,}$ fakat hala uygulamaya geçilmemiştir.

Bir diğer husus medrese için hazırlanılan projelerde yapının onarım sonrası işlevinin tam olarak belirlenmemiş olmasıdır. Proje hazırlanırken medresenin işlevine karar verilmediği için yapı onarım sonrasında herhangi bir işlev ile ilişkilendirilmektedir. Bu durum yapının korunmasında uzun vadede olumsuz durumların ortaya çıkmasına neden olmaktadır. Ayrıca yapılan altyapı çalışmaları ile yeni kullanım önerisi birbirine uyum göstermemektedir. Dolayısıyla, yapılan müdahaleler, kullanım yükü, getirilen ekler vb. konularda artışa neden olmaktadır. Kültür varlığının özgün işlevi dışında başka bir işlev için kullanılması yönünde alınan kararın gerektirdiği müdahalelerin bir koruma projesi kapsamında uygulanması gerekir.

Onarım uygulamalarında yaşanan sorunlardan birisi de, şantiyede sıva raspası yapıldıktan sonra ortaya çıkan detaylara göre revize edilen projelerin 3 ay ile 2 yıl arası süren kurul onaylarının çok uzun zaman alması ve müteakiben işin hızlıca yetiştirilebilmesi adına olumsuz hava koşullarına rağmen uygulamaların hızlıca imal edilmek zorunda kalınmasıdır. Bu olumsuz durum, 01 Ocak 2019'dan itibaren İstanbul'daki uygulamalarda uygun olmayan hava şartlarında çalışılmama önleminin Çevre ve Şehircilik Bakanlığı genelgesi ile Ümraniye, Sancaktepe, Eyüp, Çatalca, Çekmeköy, Arnavutköy İlçeleri dışında (bu ilçeler için genellikle Ocak ayı içinde çalışılmaması öngörülmektedir) çalışmaya engel gün olmadığının kararının alınmış olması ile devam edecektir (24.09.2018 tarih, 19644152010.06.02/1615-166191 sayılı karar uyarınca).

Şantiye çalışmalarındaki müdahaleler ve seçilen yeni malzemelerin niteliğinde de sorunlarla karşıllaşılmaktadır. İhale kanunundaki açıklardan faydalanan kimi deneyimsiz firmalar, koruma uzmanı olmayan, ya da yapının yapıldığı dönem konusunda uzmanlığı bulunmayan mimarlarla çalışmakta, niteliksiz malzeme ile yapılan onarımlar sonrası kısa süre sonunda yapılarda sorunlar baş göstermektedir. Eksik ve hatalı onarımlarla kullanıcılara tahsis edilen yapılarda ortaya çıkan sorunlara da kullanıcıların müdahale etmeleri öngörülmektedir. Oysa, onarımların doğru biçimde uygulanması, yönetimlerin temel görevidir (Ekimci 2013:81). Mimari koruma, koruma etiğine uygun olarak bilimsel ve sistemli araştırma ve değerlendirmelere dayanmalıdır. Gerektiğinde onarımları denetleyecek bir bilim kurulu oluşturulmalıdır. Yine şantiye aşamasında karşılaşılan sorunlardan biri, uygulanacak yeni işlev için yapının özgün kimliği ve algısını bozacak bazı uygulamaların yapılmasıdır. Bunlar içinde oldukça sık görülen müdahalelerden biri revakların kapatılmasıdır. Bu uygulamanın yapıya zarar vermeden hafif ve geri-döndürülebilir malzemeler ile yapılanları olmakla birlikte, çok ağır müdahalelerin de uygulandığı gözlemlenmiş̧ir. Örneğin günümüzde sağlık merkezi olarak kullanılan Üsküdar Mihrimah Sultan Medresesi’nde, uygulama projeleri onaylanmadan başlanan inşaatta, avludaki ağaçlar sökülmüş, dershane ve bazı hücreler duvarlar ve ara katlar ile bölünmüş veya birleştirilmiş, avlu çelik konstrüksiyon bir çatı ile kapatılmıştır (Şekil 7). Buna karşın, Hadım Hasan Paşa Medresesi’ndeki çelikcam ek uygulaması, hem teknik olarak, hem de yapıya yaklaşım olarak daha olumlu bulunmuştur.

\footnotetext{
${ }^{6}$ TC Kültür ve Turizm Bakanlı̆̆ı, İstanbul Yenileme Alanları Kültür ve Tabiat Varlıklarını Koruma Bölge Kurulu 25.12.2008 tarihli, 554 numaralı kararı uyarınca.
} 


\subsection{Periodik Bakım-Onarım Sağlanamaması}

Yukarıda bahsedilen sorunlarla birlikte kullanıcıya teslim edilen ve kullanılmakta olan medreseler ile ilgili periyodik denetimlerin yapılmadığı, yazarlar tarafından kullanıcılar ile yapılan anketler sonucunda tespit edilmiştir. Buna göre medreselerin koruma durumları etkin bir denetim mekanizması ile takip edilmemekte ve izinsiz yapılan muhdes eklerin tespit edilmesinde geç kalınmaktadır.

\section{SONUÇ:}

İncelenen medreseler, Osmanlı Klasik Dönemi’nden Osmanlı Baroğu’na uzanan üç asır boyunca üretildikleri dönemin mimari yaklaşımlarını, yapım teknikleri ve malzemesini, yapı boyut ve oranlarını sergilerler. Bu yapılar, aynı zamanda dönemlerinin eğitim anlayışı, sosyal yaşantısı ve kültürünün simgesi ve kanıtıdır. Bu kültür varlıklarının en iyi şekilde korunması, özgün malzeme, yapım tekniği ve mimari kurgularını kaybetmemeleri büyük önem taşımaktadır. Simgesel değerleriyle kentliler açısından farklılık ve saygınlık yaratabilen kültürel miras öğeleri, aynı zamanda kentte yaşayanların anılarını, o kentle olan bağlarını canlı tutarak hem kentsel aidiyetin, hem de toplumsal bir paylaşımın, birliğin ve sürekliliğin, başka bir deyişle kentsel belleğin oluşmasında büyük rol oynar (Polat ve Y1ld1z, 2018:2).

Söz konusu medreseler için uygun olan yeniden işlevlendirme kararları koruma disiplininden uzmanlar tarafından değerlendirilmeli; mimari koruma yaklaşımı, mimari mirasın bütünlüğünü, parçası olduğu sosyal ve kültürel bağlam ile birlikte dikkate almalıdır. Eğitim yapıları üzerine yapılan benzer çalışmalarla da ortaya konduğu üzere, bu yapıların bütüncül bir strateji içinde değerlendirilip korunması gereklidir (Balcan ve Binan, 2019: 260). Sözkonusu yapıların özgünlüğü, bütünlüğü ve anlamı ile bağdaşmayacak uygun olmayan kimi işlevlerle ve ağır tesisat yükleri altında değersizleştirilmesi kabul edilemez. Verilen işlevlerin yapıların mimari özelliklerini kapatmayacak, değiştirmeyecek ve hatta öne çıkaracak nitelikte olması gerekir. Bu tanıma uygun ve olumlu bir örnek olarak Üsküdar'daki Şemsi Paşa Medresesi verilebilir (Şekil 8). Kütüphane olarak kullanılan yapı, hem restorasyonu, hem de işleviyle olumlu bir örnektir. Bu işlevle hem eğitim yapısı olarak kullanılmakta, hem de kamu yararı gözetilmiş olmaktadır. Yapılan müdahaleler ise yapının özgün mimari karakterine saygı çerçevesinde uygulanmıştır. 


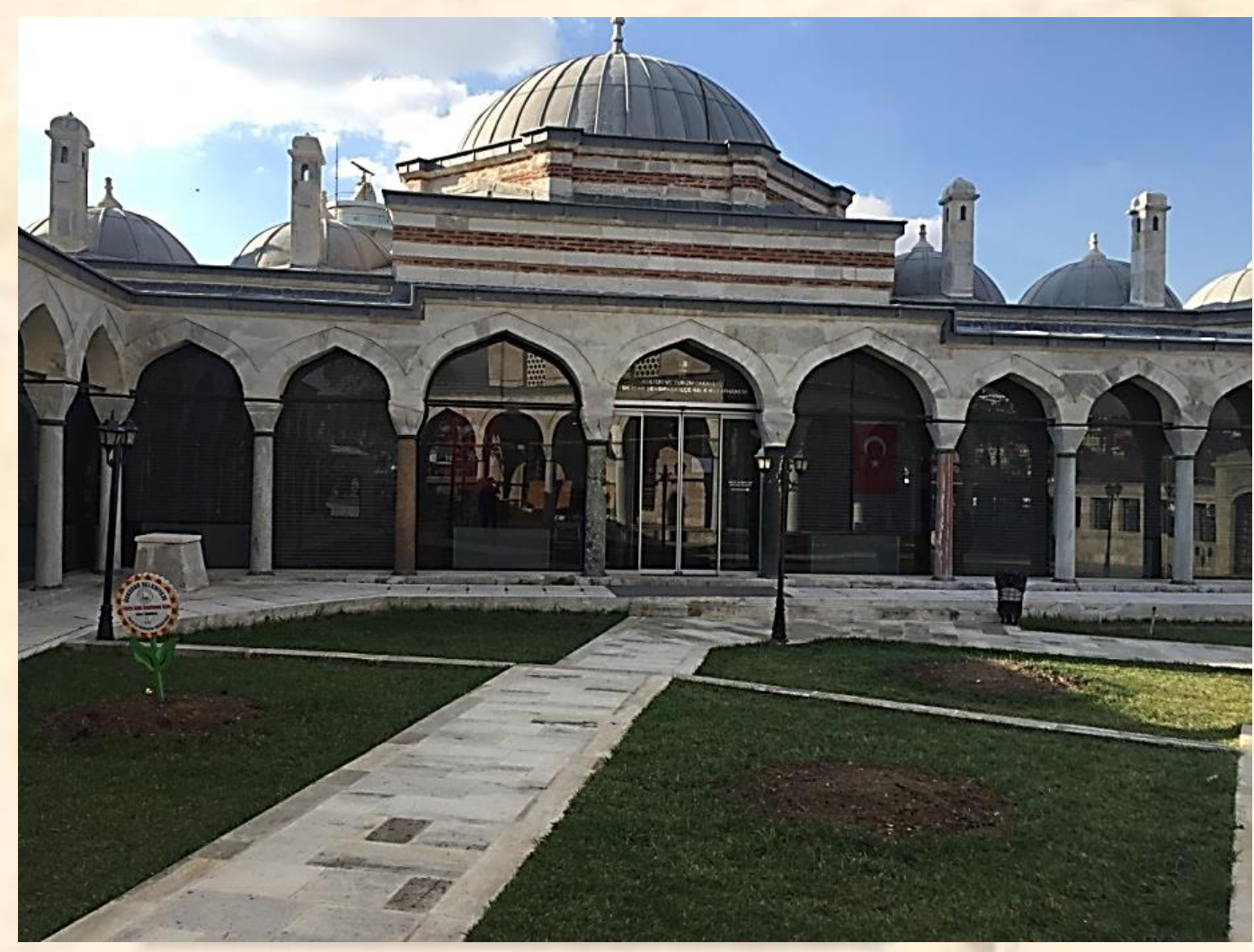

Şekil 8. Üsküdar'daki Şemsi Paşa Medresesi kütüphane işlevi ve restorasyonun niteliği ile olumlu bir örnek teşkil etmektedir (Öztürk, 2018).

Günümüzde onarılarak kamu ve vakıflar tarafından kullanılan medreseler, bu sayede halkla ilişkilerini ve eğitim işlevlerini sürdürebilmektedirler. Medrese yapılarının aynı zamanda birer kültür varlığı olduğu değerlendirildiğinde kullanıcıların faaliyet gösterdikleri alan dışında, kültürel miras ve koruma konusunda bilinçlenmeleri ve kültürel değerleri korumaya yönelik çalışmalarda bulunmaları beklenmektedir. Yeni işlevin getirdiği ihtiyaç ve taleplerin kültürel mirasın korunması önceliği açısından koruma projeleri ile belirlenmesi gerekir. Bunların sağlanabilmesi adına, kullanıcıları temsil eden STK'ların ve kamuya hizmet verme görevi üstlenen vakıfların, kültürel mirasın koruması adına yerel yönetimlerle ve koruma uzmanlarıla iş birliği içinde ve halkla karşılıklı etkileşim içinde olmalarının gerekliliği açıktır.

Çoğunluğu vakıf/dernek genel merkezi olarak kullanılan medreselerin daha ziyade kamu yapısı olarak sosyal kamu hizmetleri ile bilimsel-teknik-kültürel kamu hizmetlerinde kullanılması yapılan çalışma sonucunda tavsiye edilmektedir. Proje, ihale ve restorasyon uygulaması süreçlerinde de ciddi bir iyileştirme gerekmektedir. İhale koşulları, ihaleyi alan firmaların nitelikleri ve tecrübeleri, işin süresinin belirlenme koşulları, uygulamalar ve uygulama sonrasında yapılması gereken denetimler için mekanizmalar geliştirilmeli, restorasyon ihalesine çıkmadan önce doğru ihale usulünün seçilmesi sağlanmalıdır. Medreselerin bütünü için sürekli bir bakım-onarım programının oluşturulması öncelikli olarak ele alınması gereken düzenlemelerden biridir. Medreseler için ayrıca her yapıya özel bir kullanım talimatnamesi oluşturulmalı; medrese kullanıcısına tahsis edilirken, sözleşmenin bir parçası olarak Vakıflar Genel Müdürlüğü ile kullanıcı tarafından karşılıklı olarak imzalanması sağlanmalıdır. Böylece medrese için 
oluşturulan bu kullanım kılavuzu eşliğinde yapının daha iyi biçimde kullanılmasının ve korunmasının mümkün olacağı umulmaktadır.

\section{KAYNAKÇA:}

Ahunbay, Z. (1988). Mimar Sinan'ın Eğitim Yapıları. Mimarbaşı Koca Sinan, Yaşadığı Çağ ve Eserleri, İstanbul, Türkiye: Vakıflar Genel Müdürlüğü Yayınları.

Ahunbay, Z. (1993). "Medrese”, DBİA, Cilt: 5, s.321-325, Kültür Bakanlığı-Tarih Vakfı ortak yayını, İstanbul, s.321-325.

Araz, Y. (2013). 16. yüzyıldan 19. yüzyıl başlarına Osmanlı Toplumunda Çocuk Olmak, Kitap Yayınevi, İstanbul.

Balcan, C., Binan, D., U. (2019). “Mimar Sinan’ın Sıbyan Mekteplerinin Mimarî Özellikleri ve Modüler Tasarımı Üzerine Bir Araştırma", Uluslararası Hakemli Tasarım Mimarlık Dergisi, sayı:16, s.229-268.

Benli, G., Özer, D., G. (2018). "Kent Kimliğinin Tanımlanmasında Kültür Envanterinin Rolü: Bitlis Sivil Mimarisi”, Uluslararası Hakemli Tasarım Mimarlık Dergisi, sayı:13, s.92-124.

Beydilli, K., (1995). Türk Bilim ve Matbaacılık Tarihinde Mühendishane, Mühendishane Matbaası ve Kütüphanesi (1776-1826), Eren Yayıncılık, İstanbul, s.9.

Ekimci, B., 2013, "Vakıf Eserlerin Restorasyonu ve Üsküdar Selimiye Camisi”, Mimarlık Dergisi, sayı:372, s.7581.

Ekimci, B., Ahunbay, Z. (2016). "Üsküdar'ın Vakıf Eser Kültür Mirası ve Korunması için Öneriler”, Vakıf Restorasyon Yıllığı, Sayı:12, s. 6-16.

Eyice, S. (1979). “Osmanlı Medreselerinin Mimarisi”, MEB İslam Ansiklopedisi, cilt:8, s.116-118, Milli Eğtim Basımevi, İstanbul, s.116-118.

Kasmo, R. (2008), Restoration Project of al-Ahmadiyya School in Aleppo. master thesis, lstanbul Technical University, lnstitute of Science and Technology.

Kodaman, B. (1980). Abdülhamid Devri Eğitim Sistemi, Türk Tarih Kurumu Yayınları, VIII. Dizi, Sayı:94, İstanbul.

Kurşun, Z. (2008). Yaşayan İstanbul Medreseleri, İ.B.B. Yayınları, İstanbul, s.36.

Kütükoğlu, M. S. (2000). XX. Asra Erişen İstanbul Medreseleri, XXVII. Dizi, Sayı:4, Türk Tarih Kurumu, İstanbul.

Necipoğlu, G. (2005). The Age of Sinan, Architectural Culture in the Ottoman Empire, Reaktion Books, London..

Polat, S., Yıldız, Ö., T. (2018). Kültürel Miras Alanlarında Kentsel Tasarım ve Toplumsal Katılım: Bursa Hanlar Bölgesi Örneği, Uluslararası Hakemli Tasarım Mimarlık Dergisi, sayı:15, s.1-44.

\section{Internet Kaynakları}

http://orcp.hustoj.com/2016/04/02/icomos-charter-principles-fora-the-analysis-conservation-andstructural-restoration-of-architectural-heritage-2003/ (E.T. 14.05.2019).

\section{EXTENDED ABSTRACT}

The fact that Istanbul was an important center of science, education, and culture as the capital of the Ottoman Empire gave way to the construction of many educational structures in the capital as a natural consequence of this. The madrasas, which occupy an important place in the historical urban fabric of Istanbul, were established as institutions of higher and secondary education and served for the research and dissemination of Islamic theology. In the Islamic world, the madrasas, which were supported and guided by the state from the Seljuk-Period onwards, contributed to the public debate, discussion, and evaluation of the social issues affecting the public in political and power struggles.

The Semaniye Madrasas built within the complex of Mehmed II (1451-1481) provided Istanbul to become a capital of science besides being the center of the state in the $15^{\text {th }}$ century. The development period for the madrasas as institutions of secondary and higher education continued until the end of the reign of Süleyman I (1520-1566). However, in the 16. Century, during the reign of Sultan Murad III (1574-1593) a degeneracy in the madrasas began and in the 18. Century, the progressive corruption of the madrasas culminated with the fact that Ottoman education was far behind the level in the European countries. Since the end of the 18th century, concurrent reforms in education were applied: a school of engineering and a medical school were established as contemporary higher education institutions. During the reign of Mahmud II (1808-1839), secondary education 
institutions were improved. Starting from Istanbul, the necessity of making the primary schools mandatory with an edict of 1824 was one of the fundamental changes in the $19^{\text {th }}$ century. During the modernization process, which was also called the Westernization period in the $19^{\text {th }}$ century, the changes in the educational system led to changes in the architecture of the educational structures.

In this paper, madrasas built between the $16^{\text {th }}-18^{\text {th }}$ centuries, starting with the Ottoman classical style and ending with the Ottoman Baroque style until the beginning of the radical changes in the $19^{\text {th }}$ century, were handled. The structures were identified and evaluated in terms of their historical and architectural features and their current problems of preservation. Until recently, the great majority of the previous studies on the madrasas regarding their state of preservation focused on a single structure rather than an overall evaluation of the madrasas as cultural assets. This paper tries to determine how the functions and regulations affected the madrasas, which were in use with new functions after their existence as institutions of education was ended in 1924 by the Turkish Republic.

With the help of the archival documents and photographs, a comparison of the past and present states of preservation for the madrasas was accomplishable and besides, the previous repairs of the structures were examined. A field study, comprising visits to all madrasas, enabled determination of their current problems of conservation. Moreover, interviews which were conducted with the managers-in-charge helped to evaluate the approach of the current users towards the cultural heritage and its values. Therefore an overall evaluation was possible regarding their functions and how the implementation of these functions following the will of the users who want to benefit the modern technologies regardless of the structures' historical values affected these structures.

To sum up, in the study, the locations of madrasas, their plan types, known repairs, registration status and dates as cultural assets, relevant decrees of the board of conservation, known and current functions were examined. The problems of conservation were identified and some recommendations are stated. It is recommended that the madrasas, which are mostly used as the headquarters of the foundations/guilds, better be used in the social public services and scientific-technical-cultural public services. Significant improvement is also required in qualifications in the preparation of the projects for their restorations and implementation of the restoration procedures. These valuable structures present several challenges in both diagnosis and implementation, beyond the mere application of restoration techniques ${ }^{7}$.

Current functions of the madrasas after their repairs partially maintain the public relations and their educational functions which they possessed when they were founded. Considering that these structures are also cultural assets, their users are expected to be aware of cultural heritage and its values. The needs and demands regarding a new function to a madrasa should be determined within the scope of the conservation projects by experts in terms of prioritizing the preservation of cultural heritage. To provide these, it is clear that the NGOs that represent the users and the foundations that serve the public should interact with the local authorities and conservation experts. A permanent maintenance and repair program for all madrasas is one of the priorities. For each madrasa, a special instruction manual should be created and must be an integral part of the contract of rent. So that the users are acknowledged and warned about the limits which would prevent them from giving harm to these valuable structures. And thus, these important monuments can be preserved as they deserve.

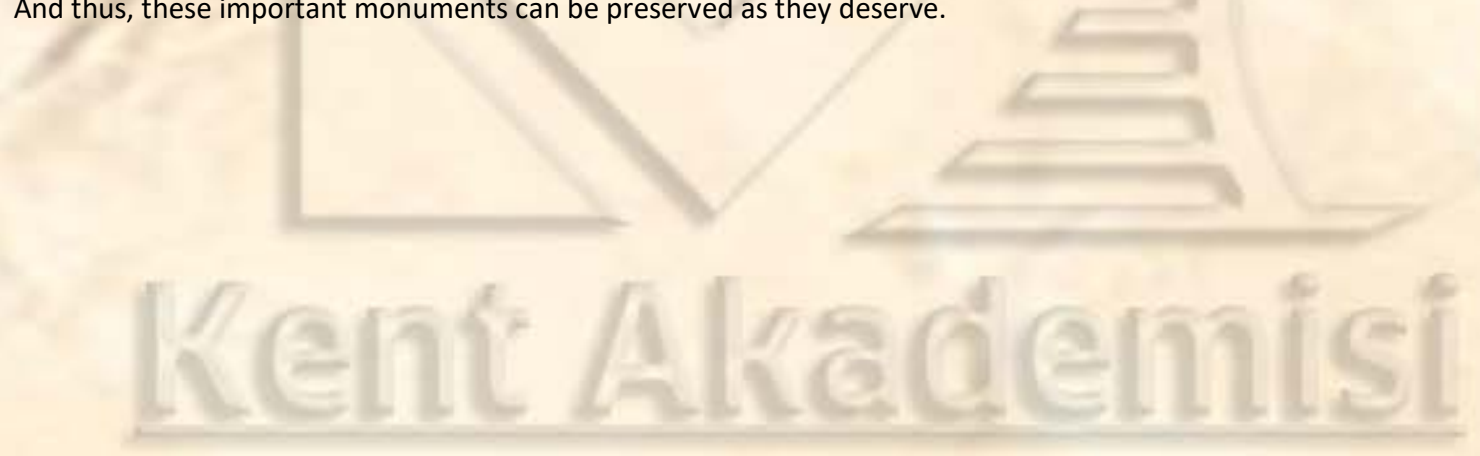

${ }^{7}$ ICOMOS Charter - Principles for the Analysis, Conservation and Structural Restoration of Architectural Heritage (2003)/ http://orcp.hustoj.com/2016/04/02/icomos-charter-principles-fora-the-analysis-conservation-and-structural-restoration-of-architectural-heritage2003/, item 1.6, p.1. 